UDC 343.131

DOI: https://doi.org/10.32631/pb.2020.1.18

NCHOUTU VERALINE ESPE MINANG,

Senior Lecturer in Law, University of Dschang Cameroon;

NANA CHARLES NGUINDIP,

Senior Lecturer in Law, University of Dschang Cameroon;

e-mail: seniorlecturer84@gmail.com

\title{
AN ANALYSIS OF THE LEGAL STANDARD IN THE FIGHT AGAINST TORTURE AND TREATMENT OF PRISONERS UNDER INTERNATIONAL LAW: WHAT PROSPECT FOR APPLICATION UNDER CAMEROONIAN LAW?
}

\begin{abstract}
This article seeks in highlighting the fact that prohibiting torture, cruel, inhumane and degrading treatment of persons is an important aspect of human right specificities articulated in relevant human right dispositions especially the main Universal Declaration of Human Right 1948, and has given responsibilities to States in ensuring the effective protection of this right by preventing their violations. The article also indicates that, though this right has occupied an international recognition to States who are parties to the available relevant dispositions, violating its provision will constitute grave injury and arbitrary treatment on the dignity and integrity of the human race. Cameroon in its compliance with the international standard set, has contributed enormously by enacting credible laws which varies from its constitution, criminal codes, and other relevant provision all in the aim of safeguarding and ensuring that this right should be treated with lots of human protection and security. Even though with efforts laid in place by the country through its various legal and institutional dispositions, prohibition and protection has continued to be considered as a nightmare, as we continue in experiencing violations of this fundamental right by those who were vested with the powers and competent in ensuring and securing this sacred right. The violations experienced have really provoked lots of questioning as to the place occupied, and the outcome of the Cameroon Human Right system in combating and punishing those who interrupts the assurance of this fundamental human right?
\end{abstract}

Key words: Legal Standard, Torture, Degrading Punishment, International law, Cameroon.

Introduction

A cardinal adage of international human right law is that the prohibition against torture, cruel, inhuman and degrading treatment is absolute in its determination and application where the common placement is that no exception whether justified or defended, is tolerated in any circumstances whatever may be the case in question. The aspect of torture is an important issue in matters of crimes determination and it seeks to annihilate the victim's personality and denies the inherent dignity of the human being. The United Nations with it primary function in ensuring that aspect of fundamental human right as spelled out in relevant human right treaties and instruments from the international, regional and even national should be respected by all. It continues by condemning torture in its outset as one of the vilest acts perpetrated by human beings on their fellow creatures. As a crime generally recognised in International $\operatorname{law}^{1}$ with the

1 Rome Statute of the International Criminal Court 1988 in its article 7 make reference of the offence of torture. enactment of relevant legal dispositions, it is absolutely prohibited and cannot be justified under any circumstances. The prohibition in question to an extent are considered as a form or part of customary international law binding every member of the international community, regardless of whether the said State has ratified international treaties in which torture is expressly prohibited. In upholding this sacred and inherent right, a plethora of legal instruments like the Convention Against Torture being the primordial euphoria in the fight against torture has stipulated in its Article 1 that «any act by which severe pain or suffering, whether physical or mental, is intentionally inflicted on a person for such purposes as obtaining from him or a third person information or a confession, punishing him for an act he or a third person has committed or is suspected of having committed, or intimidating or coercing him or a third person, or for any reason based on discrimination of any kind, when such pain or suffering is inflicted by or at the instigation of or with the consent or acquiescence of a public official or other person acting in an official capacity». 
Cameroon as one of the signatories and party to most of the recognised and acceptable human man right treaties has recognised this right in its constitution especially the preamble which provide that «every person has the right to life, physical and moral integrity and to humane treatment in every circumstances. That under no circumstances shall someone be subject to torture, inhumane and degrading treatment» ${ }^{1}$.

The constitution continues by affirming the attachment of the people of Cameroon to the fundamental freedoms enshrined in the Universal Declaration of Human Rights, the Charter of the United Nations and the African Charter on Human and Peoples' Rights, and all duly ratified international conventions relating thereto. Article 45 of the Constitution provides that «duly approved or ratified treaties and international agreements shall, following their publication, override national laws, provided the other party implements the said treaty or agreement» ${ }^{2}$

Despite commitments made by the Cameroonian authorities to respect national law and international human rights standards in their operations, the evidence witness is that arbitrary arrests and detentions continue on a large scale in Cameroon, and even the basic legal safeguards relating to arrest and detention are rarely respected. Our worry here is not in questioning whether Cameroon as a party to numerous international human right instruments as to torture has comply with the provision of these human right treaties? It is but right the country in context has contributed enormously in ensuring that aspects of torture and degrading treatment should be given special attention and interest, but it will be proper for us for the sake of efficient understanding, have an inside of what aspects of torture is all about before warranting the application by the State of Cameroon.

1.1. A general recognized and Acceptable right under the Convention Against Torture.

Neither the Universal Declaration on Human right nor the International Covenant on Civil and Political Rights has been able in providing a unique or succinct definition of the concept of torture. Notwithstanding the lacunae provided by these human right treatises, a more specific

1 Law no.96/06 of 18 January 1996 to amend the Constitution of $2^{\text {nd }}$ June 1972 . Article 65 of this Constitution is to the effect that the preamble is an integral part of the constitution.

2 It should, however, be noted that the international protection of Human Rights has adopted the idea of diplomatic immunity which should water down the provisions of article 45 . instrument has elucidated on what will be seen as torture. According to this Convention, torture means: "Any act by which severe pain or suffering, whether physical or mental, is intentionally inflicted on a person for such purposes as obtaining from him or a third person information or a confession, punishing him for an act he or a third person has committed or is suspected of having committed, or intimidating or coercing him or a third person, or for any reason based on discrimination of any kind, when such pain or suffering inflicted by or at the instigation of or with the consent or acquiescence of a public official or other person acting in an official capacity» ${ }^{3}$

In determining that an act or omission will amount to torture does not automatically entails that there must be the existence of pain or suffering on the person in question, but the person undergoing this severe pain or suffering should be able in proving that the act imposed on him or her by the public official is causing serious bodily harm and coercion for it in attracting lawful sanctions. It is in this respect that a responsibility has been imposed on every State, member of the said convention in prohibiting any cruel, inhuman, or degrading treatment against anyone undergoing detention or imprisonment. It is important to clarify that, the definition as provided by the Convention should be observed in its wide application and understanding. Placing the act of torture and degrading punishment will have to be giving lots of interpretation. For there must not only be the present of both physical and mental suffering constituting torture, but that, for suffering experienced by the prisoner in question must purposefully be inflicted by a competent and recognised public official acting in such capacity.

\subsection{A Complementary Standard and} Appreciation of International Covenant on Civil and Political Right 1966.

As a common understanding, the 1966 International Covenant on Civil and Political Rights (ICCPR) was the first in its kind considered as a general universal human rights treaty in explicitly including the prohibition of torture and other cruel, inhuman or degrading treatment. The main aim of this law was in protecting both the dignity, physical and mental integrity of every individual suffering from the effect of crime commission and undergoing trial and prosecution. ${ }^{4}$ The two most important relevant

${ }^{3}$ Article 1 on the United Nation Charter Against Torture 1984.

${ }^{4}$ Human Right Committee, General Comment No. 20, "Prohibition of torture, or other cruel, inhu- 
provisions of the ICCPR underlying particularly to this prohibition is Article 7. Article 7 of the Covenant stipulate as follow «No one shall be subjected to torture or to cruel, inhuman or degrading treatment or punishment. In particular, no one shall be subjected without his free consent to medical or scientific experimentation».

Looking at the provision of article 7 the elements such as the victim's age and mental health may therefore aggravate the effect of certain treatment so as to bring it within Article 71 . Nevertheless, it is not satisfactory that treatments are capable of producing an adverse physical or mental effect; it must be proven that this has occurred in a specific case of violations. ${ }^{2}$ In contrast to the United Nations Convention against Torture and Other Cruel, Inhuman or Degrading Treatment or Punishment examined above, the ICCPR failed in its part in ensuring the level of involvement or acquiescence by a State official for an act to be qualified as torture or illtreatment. Rather, it is the duty of the State Party to afford everyone protection through legislative and other measures as may be necessary against the acts prohibited by Article 7, whether inflicted by people acting in their official capacity, outside their official capacity or in a private capacity.

This provision in question therefore covers all forms of treatment which would not be sufficiently severe to qualify as cruel, inhuman or degrading under Article 7.3 Emphasis should be made here that Article 10(1) in its application provide general conditions of detention, reserving Article 7 for situations where an individual is subjected to specific attacks on his or her personal integrity. ${ }^{4}$

man or degrading treatment or punishment" (1992) $\S 2$, in UN Doc. HRI/GEN/1/Rev.7.

${ }^{1}$ Torture in International Law, A guide to jurisprudence, 2008, p. 8

${ }^{2}$ Vuolanne v Finland, HRC Communication No. 265/1987, 7 April 1989, §9.2.

${ }^{3}$ HRC, General Comment No. 29, "Derogations during a state of emergency", P.13(a), in UN Doc. HRI/GEN/1/Rev.7.

${ }^{4}$ Kennedy $v$ Trinidad and Tobago, HRC Communication No. 845/1998, 26 March 2002, §§7.7- 7.8. In this case, the author was kept on remand for a total of 42 months with between five and ten other detainees in a cell measuring 6 by 9 feet. Following his trial, he was detained for a period of almost eight years on death row, during which he was subjected to solitary confinement in a small cell with no sanitation except for a slop pail and no natural light. He was allowed out of his cell only once a week, and provided with wholly inadequate food that did not

\subsection{The Necessity of Other Human Right Instruments.}

The four Geneva Conventions for the Protection of Victims of Armed Conflict" promulgated in $1949^{5}$ in complementing the United Nation Universal Declaration on Human Right strictly reinforce the implementation of human right when issues of hostilities and armed conflict are concerned. The convention has gone a long way in ensuring and prohibiting aspect of torture to be experienced by those suffering from the effect of armed conflict. The Third Geneva Convention relates to the protection of prisoners of war, and in relation to international armed conflict by providing in its Article 17 that: «No physical or mental torture, nor any other form of coercion, may be inflicted on prisoners of war to secure from them information of any kind whatever. Prisoners of war who refuse to answer may not be threatened, insulted, or exposed to unpleasant or disadvantageous treatment of any kind».6

In complementing this provision, Article 32 of the Fourth Geneva Convention provides that during periods of international armed conflicts, including periods of military occupation, no measure can be taken of such a character as to cause the physical suffering or extermination of protected persons. ${ }^{7}$ This prohibition applies not only to murder, torture, corporal punishment, mutilation and medical or scientific experiments not necessitated by the medical treatment of a protected person, but also to any other measures

take into account his particular dietary requirements.

${ }^{5}$ Geneva Convention for the Amelioration of the Condition of the Wounded and Sick in Armed Forces in the Field, Aug. 12, 1949, 6 U.S.T. 3114, 75 U.N.T.S. 31 (entered into force Oct. 21, 1950) [hereinafter Geneva Convention I]; Geneva Convention for the Amelioration of the Condition of Wounded, Sick and Shipwrecked Members of Armed Forces at Sea, Aug. 12, 1949, 6 U.S.T. 3217, 75 U.N.T.S. 85 (entered into force Oct. 21, 1950) [hereinafter Geneva Convention II]; Geneva Convention Relative to the Treatment of Prisoners of War, Aug. 12, 1949, 6 U.S.T. 3316, 75 U.N.T.S. 135 (entered into force Oct. 21, 1950) [hereinafter Geneva Convention III]; Geneva Convention Relative to the Protection of Civilian Persons in Time of War, Aug. 12, 1949, 6 U.S.T. 3516, 75 U.N.T.S. 287 (entered into force Oct. 21, 1950) [hereinafter Geneva Convention IV].

${ }^{6}$ Article 17 of Geneva Convention III of the 1948 Geneva Convention dealing with the treatment of Prisoners of War

${ }^{7}$ Article 32 of Geneva Convention IV dealing with the protection of the Civilian Population. 
of brutality whether applied by civilian ${ }^{1}$ or military agents. Torture or inhuman treatment willfully causing great suffering or serious injury to body or health constitutes a grave breach under the Third and Fourth Geneva Conventions. ${ }^{2}$

At the African level, great implications are referred to Article 5 of the African Charter which provides that every individual shall have the right to the respect of the dignity inherent in a human being and to the recognition of his legal status. That all forms of exploitation and degradation of man particularly slavery, slave trade, torture, cruel, inhuman or degrading punishment and treatment shall be prohibited. ${ }^{3}$

With all these explanation established as to the provision of a definition and understanding of the concept of torture and degrading treatment in relevant human right disposition, it is still clear that there exist complexities in coming out with a clear indication of what will really amount to an act of torture. To this effect, in having a deep inside on this concept of torture, there will be a well profound need in examining the analysis of the constituent elements of the concept of torture.

\subsection{Understanding the Constituent Element of Torture and Degrading Treat- ment: A Possible Platform.}

However, for the purpose of this work, not all act of cruel, inhuman or degrading treatment may amount to torture, either because it does not have the same purposes as torture, or because it is not intentional, or perhaps because the pain and suffering is not severe within the meaning of Article 1 of the Convention. It is therefore instructive to analyse these aspect so as to have an inside of the distinction that exist between torture and degrading treatment.

\subsection{Assessing the Severity and Gravity of Pains Experienced.}

In common and normal parlance, the intuition and proof of acts of torture has experienced lots of difficulties in its establishment. The normal credo here is that for an act to amount to

${ }^{1}$ Geneva Convention IV, supra note 14 , at article. 32 .

2 Geneva Convention III, supra note 13 , at article. 130; Geneva Convention IV, supra note 15, at article. 147.

${ }^{3}$ African Charter on the Rights and Welfare of the Child, arts. 16-17, OAU Doc. CAB/LEG/24.9/49 (1990) (entered into force Nov. 29, 1999), Protocol to the African Charter on Human and Peoples' Rights on the Rights of Women in Africa, article 4, July 11, 2003, OAU Doc. CAB/LEG/66.6 entered into force November. 25, 2005). torture, basic aspect such as the severe pain or suffering must be present in all its descriptions, ${ }^{4}$ and must universally deemed a basic feature if not the ship anchored criterion for determining the act of torture [1]. Torture simplicita does not automatically means hurting a person [2]. In its most traditional and parachutes understanding, torture must be given a place at the summit of the pyramid of agony. ${ }^{5}$ As a result, one immediately gets the impression that a general consensus exists that established the threshold of pain or suffering set for torture [3], and such pain and suffering is higher than that for other illtreatment. ${ }^{6}$ This idea that only the severest abuse can be designated as torture, is an essential requirement in having close recognition and distinction between the two concepts. To this regards, the intention of Article 1 (2) place torture in its aggravated form of inhuman, cruel or degrading treatment and punishment. ${ }^{7}$ However, even with this at place, determining that a specific higher threshold exist for torture to be admissible has proved to be a great challenge. There is in fact no red line, plain for all, which should be crossed for acts or omissions to become torture. Clearly and precisely speaking, there has been no clear threshold and, it practically impossible in obtaining one which will amount to torture. One just needs to examine all the acts of torture in concreto so as to determine the severity and gravity of the pains and suffering incurred by the prisoner in question. As the law puts it, 8 the term severe is in the nature of things or offence relative to the act and harm committed on the person experiencing the omission and treatment. ${ }^{9}$ In every stage or circumstance, the act of torture must be evaluated, from the duration

${ }^{4}$ Art. 1 of the United Nations General Assembly, Torture Declaration; Art. 1 United Nations Convention Against Torture; Art. 7 (2) (e) of the Statute of the International CC; Art. 7 (1) (f) 1. Elements of Crimes ICC (torture as a crime against humanity); Art. 8 (2) (a) (ii)-1 1. and 8 (2) (c) (i)-4 1. Elements of Crimes ICC (torture as war crime); Sections 5.2 (d) and 7.1. Statute Special Panels.

5 Aksoy v. Turkey, Appl. No. 21987/93, Judgment, 18 December 1996, para. 63.

6 Prosecutor v. Kvočka et al., Case No. IT-9830/1-T, Trial Chamber, Judgement, 2 November 2001, para. 226; Prosecutor v. Martić, Case No. IT95-11-T, Trial Chamber, Judgement, 12 June 2007, para. 75.

7 The United Kingdom, Appl. No. 5310/71, Judgment, 18 January 1978, para. 167.

${ }^{8}$ Art. 1 of the Convention Against Torture 1984.

${ }^{9}$ Selmouni v. France, Appl. No. 25803/94, Judgment, 28 July 1998, para. 100. 
of the treatment, to its physical and/or mental effects, down to the age, sex and even state of health of the victim, ${ }^{1}$ as well as the nature and context of the ill-treatment, and the manner and method of its execution must all be examined. ${ }^{2}$

\subsection{The Presence of a Prerequisite}

\section{Intention.}

It is of a common knowledge and exhibition that in every criminal manifestation, establishing torture entails severe pain or suffering that has been inflicted intentionally on the victim in question or under torture. ${ }^{3}$ The fact one need in portraying is whether the harm, cruelty, inhumane treatment and punishment plague on the victim was done intentionally. For any act or torture done on someone negligently cannot be embraced under the umbrella of acts amounting to torture or degrading punishment. Establishing intention by the victim experiencing such harm is a sufficient ground for torture, and such intention displaced can either be direct ${ }^{4}$ or indirect 5 . When one talks of direct intention, we are referring to that the act or harm has already been experienced by the victim whether the injury incurred is physical, mental or otherwise. At the level of indirect intention, the act must not have been committed, but from the conduct or implications, the State officials intended committing harm and degrading treatment on the victim. The issue of clarification here is that, whether the torture is direct or indirect, the perpetrator must have wanted to act or omit to act. From all indications, the act of beating, suffocating, rape, threat, electrocute, and many others which wanted to be carried out on the victim. Even though with this in place, there

${ }^{1}$ Soering v. United Kingdom, Appl. No. 14038/88, Judgment, 7 July 1989, para. 100; Askarov v. Turkey, Appl. No. 46827/99 and 46951/99, Judgment, 4 February 2005, para. 70.

2 Vuolanne v. Finland, Comm. No. 265/1987, Views, 7 April 1989, UN Doc. CCPR/C/35/D/ 265/1987, para. 9.2

${ }^{3}$ Prosecutor v. Musema, Case No. ICTR-96-13-T, Trial Chamber, Judgement, 27 January 2000, para. 285; Prosecutor v. Kunarac et al., Case No. IT-9623\&23/1, Trial Chamber, Judgement, 22 February 2001, para. 483; Prosecutor v. Martić, Case No. IT95-11-T, Trial Chamber, Judgement, 12 June 2007, para. 74; ECHR, Öktem v. Turkey, Appl. No. 74306/01, Judgment, 19 October 2006, para. 33; Inter-American Convention on Human Right, BuenoAlves v. Argentina, Judgment, 11 May 2007, para. 79.

${ }^{4}$ Prosecutor v. Limaj et al., Case No. IT-03-66-T, Trial Chamber II, Judgment, 30 November 2005, para. 238.

5 Prosecutor v. Martić, Case No. IT-95-11-T, Trial Chamber, Judgement, 12 June 2007, para. 77. still exist a subtle difference when examining the behavior and the consequences of the act in question. The main focal problematic that is always confusing is in establishing whether the conduct of the perpetrator, perpetrators really caused injury or bodily harm on the victim [4], or if he really wanted to subject the victim to pain or suffering, and was aware that the act he is committing is posing a threat on the physical and mental integrity and dignity of the victim or prisoner [5]. Anyway, the bottom line that one need in showing here is that in every criminal case, the dolus eventualis and recklessness are excluded as they appear to be insufficient states of mind for torture [6].

\subsection{The Existence of a Public Official or a}

\section{Perpetrator.}

The act or element of torture cannot be committed by itself. There has to be at least someone, perpetrator or perpetrators committing the act or omission. From all observations made, it seems that not everybody can be qualified in inflicting pains and suffering on the purported victim. According to Article 1 of the United Nations Conventions on Torture, the pain or suffering experienced by the victim should be inflicted by or at the instigation of, or with the consent or acquiescence of a public official or other person acting in the capacity of such an official. Nonetheless, emphasis has to be laid when establishing this requirement. The interpretation giving to a perpetrator or official should not have a strict or rigid manner, for it suffices that there should exist a link between the perpetrator and the person acting in an official capacity, or whether the latter is part of de jure or de facto authorities, and whether he or she acted within or outside his or her sphere of competence.

\subsection{The Victim.}

What becomes the act, cruelty, inhumane treatment where if there cannot be proof or existence of a victim. The need to be a victim of the torturous pains and sufferings for the act to be qualified or amount to torture and the victim in question must be a human being. It clear that when acts of torture are experimented on the victim, the said victim is seen in a position that he or she is powerless and helpless for the pain or suffering inflicted on him by the perpetrator, perpetrators or public officials. With this in place, one is left in a state of confusion in realizing the distinction existing between the powerlessness and helplessness of the victim posing the perpetrator or perpetrators in inflicting pains and suffering since none of the elements aforementioned is found in any international human right treatise establishing the definition of torture. Presumably, there is the tendency [7] 
that the victim is abandoned in a state of helplessness and powerlessness for such person to incur physical or mental injury. There must have been the presence of intimidation, coercion, threat, duress, and even undue influence on the part of the public official when extracting evidence or confession from the suspect or criminal in question. The situation of powerlessness and helplessness may have enable the torturer in breaking the will of the victim in providing information against his will or consent. One thing for sure is the fact that, one ought to ask what significance must be attributed to the intertwined elements of control of the perpetrator and powerlessness of the victim. Indeed, there is always a nexus existing in a state of full control by the public officials inflicting the pains and suffering, and the powerlessness truly necessary on the part of the victim? This question becomes all the more important and delicate when one takes into account the vague nature of both terms and, above all, the fact that control and powerlessness are not exclusive to torture. Accepting these elements as distinguishing features could potentially have vastly expanding consequences for this core type of ill-treatment.

\subsection{Distinction between Torture and Cruel, Inhuman and Degrading Treatment: A Necessary Explanation.}

There have been lots of debates and misunderstanding in questioning whether acts of torture can amount to cruel, inhumane and degrading treatment. The answer is in the affirmative, because aspect of torture and cruel, inhuman and degrading treatment are concepts that in most cases can sometimes be difficult to distinguish. Normally, the tendency is that there exist possibility in differentiating between degrading and inhuman treatment, but when it comes to distinguish between inhuman treatment and torture, it becomes more complicated. In legal nomenclature, torture can be considered as a severe form of inhuman treatment, but there exist no objective element of distinction between the two categories in question. Understanding the objective of each of the concept becomes problematic in explanations, since all acts at stake are usually identical and only the level of intensity/severity of the ill-treatment can be taking into account on the vulnerability of the victim. But for the fact that the distinctive element of the two concepts can sometimes be subjective, the whole complexity of this distinction can depend on certain factors such as the powerlessness of the victim, the severity of the treatment, purpose in which the treatment is carried out, and the constant evolution of the inception.

\subsection{Degrading Punishment against Prisoner: A Cameroonian Understanding.}

Cameroon have ratified international legal instruments in the field of the protection of human rights and freedoms, thereby committing itself in ensuring the fundamental rights and freedoms guaranteed by the relevant international instruments, including the right not to be torture and free from any degrading and barbaric treatment of person, especially those in detention and custody. As a state of law bind by relevant legal dispositions with the constitution considered as the grudnorm of the country, enormous efforts has been meted by the country in ensuring this fundamental human right. A laudable initiative is recognized in the country's preamble by providing that «every person has the right to life, physical and moral integrity and to humane treatment in every circumstances. That under no circumstances shall someone be subject to torture, inhumane and degrading treatment» 1 .

The constitution continues in affirming the attachment of the people of Cameroon to the fundamental freedoms enshrined in the Universal Declaration of Human Rights, the Charter of the United Nations and the African Charter on Human and Peoples' Rights, and all duly ratified international conventions relating thereto. Article 45 of the Constitution provides that «duly approved or ratified treaties and international agreements shall, following their publication, override national laws, provided the other party implements the said treaty or agreement».

The country Constitution of 2 June 1972, revised by Law no 96/06 of 18 January 1996, bans torture and cruel, inhuman or degrading punishment and treatment in conformity with the Covenant on Civil and Political Right (Art. 7) which provide that «No one shall be subjected to torture or to cruel, inhuman or degrading treatment or punishment. In particular, no one shall be subjected without his free consent to medical or scientific experimentation».

The Cameroon's Constitution, Penal Code ${ }^{2}$ and even the Criminal Procedure Code ${ }^{3}$ has forbids the use of torture and other treatment that violates human dignity and integrity. This same situation complements the Convention against Torture where it is to the effect that a State must «take effective legislative, administrative, judicial

${ }^{1}$ Law no. 96/06 of 18 January 1996 to amend the Constitution of $2^{\text {nd }}$ June 1972 (Art. 65).

2 Journal Officiel de la République du Cameroun, Code Pénal Loi no. ${ }^{\circ} 67 / \mathrm{LF} / 112$ Juin 1967.

${ }^{3}$ Law no. ${ }^{\circ} 2005$ of 27 July 2005 on the Criminal Procedure Code, Cameroon. 
or other measures to prevent acts of torture in any territory under its jurisdiction». ${ }^{1}$

That authority in charge in employing this right must repeatedly oversee interrogation practices and procedures with the aim of thwarting torture. The convention further states that States party have to conduct a swift and impartial investigation, and where there is reasonable ground in believing that an act of torture has been committed in any territory under its jurisdiction, it is the responsibility of such State in taking the necessary measures so as in prohibiting this. ${ }^{2}$ In enforcing this Convention of Torture, Cameroon's Constitution provides that «under no circumstances shall any person be subjected to torture, to cruel, inhumane or degrading treatment».

Cameroon's penal code criminalizes the use of torture ${ }^{3}$ in inducing a person to confess to an offense or to offer statements or related information ${ }^{4}$.

\subsection{The Cameroon Criminal Procedure} Code and its fight against torture and punishment.

In every common parlance, the constitutional provisions of every country is in meeting the requirements of international legal acts in order to guarantee the right to liberty and security of person in its utmost capacity and ability. In this regard, in a normal detention environment, there is always the need in ensuring that, those detained are being safeguarded and secured. This has been the laudable effort so far that the criminal procedure atmosphere in Cameroon has been working towards its realization. Section 263 of the Cameroon Criminal Procedure Code provides that: «1) Any person who has been illegally detained may, when the proceedings end in a no-case ruling or an acquittal which has become final, obtain compensation if he proves that he has actually suffered injury of a particularly serious nature as a result of such detention».

${ }^{1}$ Convention against Torture and Other Cruel, Inhuman or Degrading Treatment or Punishment, Art. 2(1).

2 Convention against Torture and Other Cruel, Inhuman or Degrading Treatment or Punishment, Art. 12.

${ }^{3}$ NYO WAKAI and 172 others vs. The People, the administrative authorities responsible for the maintenance of law and order proceeded to arrest persons suspected of being involved in the destruction of property and other criminal acts committed during public manifestations, which led to the state of emergency in the North West Province in October 1992.

4 Journal Officiel de la République du Cameroun, Code Pénal Loi no. ${ }^{\circ} 67 / \mathrm{LF} / 112$ Juin 196.
The general and acceptable principle is that, any person deprived of his or her liberty retains human rights and fundamental freedoms ${ }^{5}$, except for restrictions required by the very fact of their imprisonment. Section 122 of the Cameroonian Criminal Procedure Code also provides that «the suspect shall be treated humanely both morally and materially». 6

4.2. Prohibition of act of Torture and Degrading Treatment of Prisoner: An Unavoidable Nightmare in Cameroon.

While the prohibition of torture is firmly established under treaty and customary law, its effective implementation remains a challenge for most States, including Cameroon.

\subsubsection{The «Inclusion» of torture mecha-} nisms in National Security Measures.

Torture as a silent national security measure is utilized within the State constituted orders begins with illegal arrest. Generally, arrests are made on warrant against persons if the offences for which the arrest warrant is punishable with loss of liberty, or in the case of imprisonment sentence or if the defendant and/or accused is at large ${ }^{7}$. Although it may neither be express nor explicit and regular mechanism, it is often adopted by the government and/or private individuals in contradiction of the provisions of the Cameroon Legal arsenal which include international legal instruments such as the CAT, ICCPR and the Criminal Procedure Code. While it must be acknowledged that the law permits arrest without warrant in cases of flagrante delicto, and which, the accused has to be presented before a magistrate for arraignment and issuance of a remand warrant, that has not always been the case.

This has been the case in the on-going war in the North West and South West Regions of Cameroon [8], and within the context of the war against Boko Haram [9]. This is not to say they are the only instances where in, torture is perpetrated in Cameroon.

While the CPC provides a maximum time of arrest and detention in cases of simple offences for no longer than 24 hours, it specifically define general pre-trial detention period to be 48 hours renewable once which can only exceptionally be extended with a written approval of the State Council twice. During investigative process, the law provides that accused persons who have no known residence and cannot fulfil any of the

5 UN Basic Principles for the Treatment of Prisoners, Principle 5.

6 Cameroon's Criminal Procedure Code, Law $\mathrm{n}^{\circ} 2005$ of 27 July, Section 122.

${ }^{7}$ Section 18(1) of the Criminal Procedure Code. 
conditions referred to in section $246(\mathrm{~g})$ of the CPC be presented before the State council if there is strong evidence against him. on the other hand, an accused person with a known residence and can fulfil the requirements provided in section 246 (g) could be released on bail. Furthermore, remand in custody is described to be an exceptional measure in cases of misdemeanors and felonies. By implication, these provisions are meant to guarantee human rights in the administration of justice by preventing prolonged detention of suspects and eradicate overcrowding in detention centers that serve as enabling grounds for torture. But these provisions seem to be dead-letter laws as Cameroonian prisons are overcrowded, brewing and spilling torture. The outbreak of the war against Boko Haram since 2013 and the northwest and southwest Crises since 2016, has seen recurrent arbitrary arrests contravening all the legal provisions. Mass arrests will obviously create a breeding ground for torture since it is not easy managing great numbers of persons in facilities meant for a specific limited number. According to an Amnesty International Report on Cameroon 2016/17, the Kondengui prison currently houses 4000 inmates despite having a maximum capacity of 2000 [10]. This is representative of almost all prisons and detention centers in Cameroon. Overcrowding renders the constituted orders ungovernable without the employment of torture. The overcrowding itself is torture. Then, the fact that the internal management is abandoned to other hardened prisoners [11] who define their own operation rules conditioned by prisoner's means and affluence sacrifices justice and reformation on the altar of torture. Closely connected and complementary to the prohibition of torture and other inhuman and degrading treatment is a positive obligation placed on States to treat all persons deprived of their liberty humanely, with humanity and respect for the inherent dignity of the human person ${ }^{1}$. This implies a package aimed at the preservation of human rights including the non-deprivation of food and protection from corporal punishment or other treatments aimed at wearing the person physically and psychologically. By analogy, the treatment of persons detained is linked to the transparency of detention areas.

It will be practically impossible that prison administrators will ensure equitable provision of food in overcrowded prisons. Food deprivation is tortious in itself. It is an open secret that the

1 Human Rights Committee, General Comment 21 (Humane Treatment), 10 April 1992, paragraph 3.
Cameroonian penitentiary system is marked by overcrowding and therefore, the provision of food to its inmates is very challenging. Corporal punishment, the very aspect of torture because it is a constitutive element of inhuman and degrading treatment seems to be a way of life for inmates in Cameroon with State acknowledges that chaining is a disciplinary measure for prisoners [12]. Such acknowledgement exposes the wide rift between expression of political and legal will of the State and practice on the ground.

In the absence of a State of emergency, a good number of people were whisked off from the North West and South West regions to undisclosed detention centers and held incommunicado [8]. A detention center will be considered "disclosed" when it is made to the public that that is the purpose for which it is established and administered. But, if people are detained in other premises such as offices and/or private homes or even purposeful but secret detention centers, they may serve as perfect breeding grounds. Those whose purpose is shrouded with some administrative activities have been found to serve as perfect tortious chambers since they are out of view by the public eye. While it is important to ensure that citizens live with the tolerable levels of nuisance, it will be torture if suspects are arbitrarily arrested and detained incommunicado [9]. Incommunicado detention entails a whole package of issues that build up to torture.

\subsubsection{The non-prosecution of perpetrators}

\section{of torture.}

Acts of torture are evidently criminal in their nature and penalized under international 2 and these international legal instruments constitute part of the legal arsenal by virtue of article 45 of the Cameroon Constitution. Integration of these laws into the national legal system is manifested through law No. 97/007 of 10 January 1997, which incorporated the CAT into the Cameroon Penal Code. Furthermore, law No. 97/009 that outlawed the use of torture by state officials and also specified sanctions for torture perpetrators. And the preamble of the Cameroon constitution guarantees protection against torture for all Cameroonians. Safeguards are provided to ensure the protection from torture in the criminal justice system in its prohibition of nonsubjection to "any physical or mental constraints or to torture, violence, threats or any pressure whatsoever, or to deceit, insidious manoeuvres, false proposals, or any method which is likely questioning, hypnosis, the administration of drugs or to any other method which is likes to

\footnotetext{
${ }^{2}$ Art. 5 UDHR 5; Art. 7 ICCPR; Art. 5 ACHPR.
} 
compromise or limit his freedom of action or decision, or his memory or sense of judgement" 1 . By implication, if this provision is anything to go by, the supposition is that if any accused person feels submitted to violations of the rights protected in this provision, he/she can institute proceedings. Article 315 (2) prohibits the use of any confession that could be used as evidence. These provisions raise the question; Is it possible for torture victims to seek justice? Prosecution in this case implies action against the State and its agencies. CAT in its Art. $2(1)^{2}$ places positive obligations on States to ensure reparation of prejudices arising from torture. Within a context where access to justice is a constant challenge, torture committed with impunity go unprosecuted because victims simply cannot keep track or get discouraged with the challenges of accessing justice. Audacious persons who engage legal proceedings for reparations have to be tenacious to proceed to international judicial mechanisms as domestic ones will hardly rule against the government ${ }^{3}$.

\section{Conclusion}

The paper concludes that even though the right to prohibit torture, cruel, inhumane and degrading treatment is a right generally recognized in relevant human right instruments and the 1984 Convention Against Torture, it's application and implementation has been considered important especially within the context of Article 1 (1) of the 1984 Convention Against Torture dealing with prohibiting all acts of torture. With its international recognition and States responsibilities in respecting the right, many evaluates it as a fundamental right of international recognition, even though to an extent its application by States has been questionable and controversial on the grounds of violations and degrading treatment that prisoners experienced. The 1984 Convention Against Torture believes that the application of the content of Article 1(1) dealing with the prohibition of torture, should rely on State responsibilities when implementing this provision in their relevant national dispositions. The State of Cameroon being one of those States that have ratified the Convention, has contributed enormously in ensuring the smooth application of this right in traverse of its relevant national dispositions. Even though the country has provided and enacted credible policies and instruments all aimed in ensuring that those in police custody and detention should not experience degrading treatment and torture on both their physical and mental integrity, there continue in existing violations on this fundamental right by those vested with competent and capacity in securing and safeguarding rights of prisoners. The situation experienced above has become questionable and problematic, as there continue to be difficulty in the Cameroon Human right system when dealing with the integrity and dignity of its citizens, especially when cases of prisoner rights are concerned.

\section{List of References}

1. Keller L. M. Is Truth Serum ${ }^{1}$ Torture? Am. U. Int'l L. Rev. 521 (2004-2005). P. 575.

2. Burgers H., Danelius H. The United ${ }^{2}$ Nations ${ }^{3}$ Convention against Torture. A Handbook on the Convention against Torture and Other Cruel, Inhuman or Degrading Treatment or Punishment. Dordrecht : Martinus Nijhoff Publishers, 1988. Pp. 117-118.

3. Grdinic E. Application of the Elements of Torture and Other Forms of Ill-Treatment, as Defined by the European Court and Commission of Human Rights, to the Incidents of Domestic Violence. Hastings Int'l \& Comp. L. Rev. 217 (1999-2000). P. 246.

4. Clark R. S. The Mental Element in Criminal Law: The Rome Statute of the International Criminal Court and the Elements of Offences. Criminal Law Forum. 2001. No. 291. P. 330.

5. Badar M. E. Drawing the Boundaries of Mens Rea in the Jurisprudence of the International Criminal Tribunal for the Former Yugoslavia. International Criminal Law Review. 2006. No. 313. P. 321

6. Cassesse A. International Criminal Law. Oxford : Oxford University Press, 2003. P. 120.

7. Dewulf S. The Signature of Evil. (Re)Defining Torture in International Law. Cambridge : Intersentia, 2011. Pp. 363-370.

8. Cameroon Detainees Tortured: Abuse, Incommunicado Detention at Yaoundé Prison; Enforced Disappearances // Human Rights Watch. 20.08.2019. URL: https://www.hrw.org/news/2019/08/20/ cameroon-detainees-tortured (accessed 11.01.2020).

9. Cameroons Secret Torture Chambers: Human Rights Violations and War Crimes in the Fight Against Boko Haram / Amnesty International. 2017. URL: https://reliefweb.int/sites/reliefweb.int/files/ resources/AFR1767632017ENGLISH.PDF (accessed 11.01.2020).

Section 122(2) of the CPC.

2 Art. 2(1) of the CAT provides that "Each State Party shall take effective legislative, administrative, judicial or other measures to prevent acts of torture in any territory under its jurisdiction".

Albert Womah Mukong v. Cameroon, Communication No.458/1991, U.N. Doc. CCPR/C/51/ D/458/1991 (1994). 
10. Cameroon 2019 // Amnesty International Report on Cameroon. URL: https://www.amnesty.org/ en/countries/africa/cameroon/report-cameroon/ (accessed 11.01.2020).

11. Traumatic Detention Conditions in the Cameroon Kondengui Prison // Contra Nocendi. URL: http://contranocendi.org/index.php/en/news-press/120-traumatic-detention-conditions-in-the-cameroonkondengui-prison (accessed 11.01.2020).

12. Committee against Torture examines report of Cameroon // United Nations Human Rights. 09.11.2017. URL: https://www.ohchr.org/en/NewsEvents/Pages/DisplayNews.aspx?NewsID= 22384\&LangID=E (accessed 11.01.2020).

Came to the Editorial Board 15 January 2020

\section{МІНАНГ Н. В., НГУІНДІП Н. Ч. АНАЛІЗ ПРАВОВИХ СТАНДАРТІВ У БОРОТЬБІ

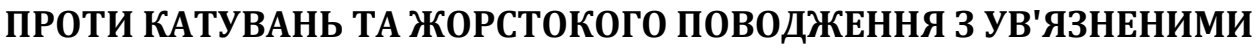 ВІДПОВІДНО ДО МІЖНАРОДНОГО ПРАВА: ЧИ Є ПЕРСПЕКТИВИ ЗАСТОСУВАННЯ ЗГІДНО ІЗ ЗАКОНОДАВСТВОМ КАМЕРУНА?}

Метою статті $\epsilon$ висвітлення того, що заборона тортур, жорстокого, негуманного та принизливого поводження з людьми $\epsilon$ важливим аспектом особливостей прав людини, сформульованих у відповідних нормативних документах з прав людини, зокрема в Загальній декларації з прав людини 1948 р., а також питання відповідальності держав у забезпеченні ефективного захисту цього права шляхом запобігання його порушення. Зазначено, що, хоча це право отримало міжнародне визнання для держав, які є сторонами наявних відповідних диспозицій, порушення його положень завдають серйозної шкоди та довільного поводження з гідністю і доброчесністю людського роду. Камерун відповідно до встановлених міжнародних стандартів зробив величезний внесок в ухвалення надійних законів, що відрізняються від конституції, кримінальних кодексів та інших відповідних положень стосовно захисту та забезпечення означеного права. Незважаючи на зусилля, докладені країною через різні їі правові та інституційні положення, заборона і захист продовжують розглядатися як жах, оскільки громадяни продовжують відчувати порушення основного права тими, хто наділений повноваженнями та компетенціями в його забезпеченні й охороні. Чи справді порушення викликали чимало сумнівів щодо місця та результату камерунської системи прав людини у боротьбі та покаранні тих, хто порушує гарантію основоположного права людини?

Ключові слова: правовий стандарт, катування, принизливе покарання, міжнародне право, Камерун.

\section{МИНАНГ Н. В., НГУИНДИП Н. Ч. АНАЛИЗ ПРАВОВЫХ СТАНДАРТОВ В БОРЬБЕ ПРОТИВ ПЫТОК И ЖЕСТОКОГО ОБРАЩЕНИЯ С ЗАКЛЮЧЕННЫМИ В СООТВЕТСТВИИ С МЕЖДУНАРОДНЫМ ПРАВОМ: ЕСТЬ ЛИ ПЕРСПЕКТИВЫ ПРИМЕНЕНИЯ В СООТВЕТСТВИИ С ЗАКОНОДАТЕЛЬСТВОМ КАМЕРУНА?}

Целью статьи является освещение того, что запрет пыток, жестокого, негуманного и унизительного обращения с людьми является важным аспектом особенностей прав человека, сформулированных в соответствующих нормативных документах по правам человека, в частности во Всеобщей декларации прав человека 1948 г., а также вопросов ответственности государств в обеспечении эффективной защиты этого права путем предотвращения его нарушения. Отмечено, что, хотя это право получило международное признание государств, являющихся сторонами имеющихся соответствующих диспозиций, нарушения его положений наносят серьезный ущерб и произвольное обращение с достоинством и добродетелью человеческого рода. Камерун в соответствии с установленными международными стандартами внес огромный вклад в принятие надежных законов, которые отличаются от конституции, уголовных кодексов и других соответствующих положений по защите и обеспечению указанного права. Несмотря на усилия, приложенные страной через различные ее правовые и институциональные положения, запрет и защиту продолжают рассматривать как ужас, так как граждане продолжают испытывать нарушения основного права теми, кто наделен полномочиями и компетенциями в его обеспечении и охране. Действительно ли нарушения вызвали немало сомнений относительно места и результата камерунской системы прав человека в борьбе и наказании тех, кто нарушает гарантию основополагающего права человека?

Ключевые слова: правовой стандарт, пытки, унизительное наказание, международное право, Камерун. 